\title{
Sperm Cryodamage in Ruminants: Understanding the Molecular Changes Induced by the Cryopreservation Process to Optimize Sperm Quality
}

\author{
Patricia Peris-Frau ${ }^{\circledR}$, Ana Josefa Soler ${ }^{*}+{ }^{\circledR}$, María Iniesta-Cuerda ${ }^{\circledR}$, Alicia Martín-Maestro, \\ Irene Sánchez-Ajofrín $\mathbb{1}^{(0,}$, Daniela Alejandra Medina-Chávez ${ }^{\circledR}$, María Rocío Fernández-Santos, \\ Olga García-Álvarez ${ }^{\circledR}$, Alejandro Maroto-Morales, Vidal Montoro and J. Julián Garde ${ }^{+(\mathbb{D})}$ \\ SaBio IREC (CSIC-UCLM-JCCM), ETSIAM, Campus Universitario s/n, 02071 Albacete, Spain; \\ Patricia.Peris@uclm.es (P.P.-F.); m.iniestacuerda@gmail.com (M.I.-C.); Alicia.MartinMaestro@uclm.es (A.M.-M.); \\ Irene.SSanchez@uclm.es (I.S.-A.); Daniela.Medina@uclm.es (D.A.M.-C.); mrocio.fernandez@uclm.es (M.R.F.-S.); \\ garciaalvarez.olga@gmail.com (O.G.-Á.); jandromaroto@hotmail.com (A.M.-M.); Vidal.montoro@uclm.es (V.M.); \\ Julian.garde@uclm.es (J.J.G.) \\ * Correspondence: AnaJosefa.Soler@uclm.es; Tel.: +34-967599200-2552 \\ + These authors contributed equally to this work.
}

Received: 29 February 2020; Accepted: 14 April 2020; Published: 16 April 2020

check for updates

\begin{abstract}
Sperm cryopreservation represents a powerful tool for livestock breeding. Several efforts have been made to improve the efficiency of sperm cryopreservation in different ruminant species. However, a significant amount of sperm still suffers considerable cryodamage, which may affect sperm quality and fertility. Recently, the use of different "omics" technologies in sperm cryobiology, especially proteomics studies, has led to a better understanding of the molecular modifications induced by sperm cryopreservation, facilitating the identification of different freezability biomarkers and certain proteins that can be added before cryopreservation to enhance sperm cryosurvival. This review provides an updated overview of the molecular mechanisms involved in sperm cryodamage, which are in part responsible for the structural, functional and fertility changes observed in frozen-thawed ruminant sperm. Moreover, the molecular basis of those factors that can affect the sperm freezing resilience of different ruminant species is also discussed as well as the molecular aspects of those novel strategies that have been developed to reduce sperm cryodamage, including new cryoprotectants, antioxidants, proteins, nanoparticles and vitrification.
\end{abstract}

Keywords: ruminant species; sperm cryopreservation; sperm cryodamage; proteomics

\section{Introduction}

Sperm cryopreservation has become an essential tool for the long-term preservation of genetically superior males, relevant transgenic lines and endangered species [1,2]. Moreover, cryopreservation facilitates the distribution of semen over distance, which has greatly contributed to the expansion of reproductive technologies such as artificial insemination and in vitro fertilization worldwide [3].

However, spermatozoa are subjected to drastic changes in temperature, ice crystal formation and diverse types of stresses (physical, chemical, osmotic and oxidative) during the cryopreservation process, which severely compromise sperm quality and fertility [4-6]. In addition, differences between species in terms of sperm size, shape and lipid-protein composition denote that the cryopreservation process is not equally efficient among all species [7]. Bulls, rams, horses and boars have been reported to generate more cryosensitive sperm than humans, rabbits, cats and dogs [8]. Aside from interspecies variability, the success of cryopreservation is also affected by many other factors like cooling-thawing rates, type of extender or cryoprotectants, sperm source (epididymal or ejaculate sperm), seasonal variations 
and even by inter- or intra-individual variations $[9,10]$. Thereby, increasing our knowledge about the molecular modifications suffered by sperm through the cryopreservation process will aid the optimization of the current freezing-thawing protocols for a better preservation of sperm functionality and fertility. In recent years, the use of different omics technologies in the field of sperm cryobiology has led, among other things, to a greater understanding of those structural and functional changes experienced by sperm during the freezing-thawing process as well as the identification of relevant freezability biomarkers [4,11,12].

Novel findings about the effects of sperm cryopreservation have led to the development of new techniques and methods of cryopreservation, where different proteins, antioxidants and cryoprotective agents are being incorporated into the freezing medium for increasing sperm cryosurvival. Such improvements, however, have not yet reached the desired level because many sperm still lose their viability after cryopreservation [13]. Therefore, the enhancement of sperm cryopreservation outcomes remains a major challenge, especially in ruminant animals, which include cattle, sheep, goat, buffalo, deer and other wild species. This group of mammals, which is widespread around the world, constitutes important food sources (meat and milk) and contributes to maintaining a sustainable agriculture due to these mammals' ability to feed on those fibrous vegetables or by-products that cannot be used as human food [14].

This review explores how those molecular elements (proteins, lipids, ARNs, epigenetic marks, etc.) altered by sperm cryopreservation can affect the different structures or functions of ruminant sperm. In addition, the molecular mechanisms involved in the sperm freezing resilience of different ruminant species are further discussed as well as the molecular aspects of those new approaches to improve the sperm cryopreservation outcomes in ruminants, such as new cryoprotectants, antioxidants, proteins, nanoparticles and vitrification.

\section{Unraveling How the Molecular Damage Caused by the Freezing-Thawing Process Affects Sperm Structure and Function}

In general, sperm cryopreservation has been reported to induce an increase in plasma membrane fluidity-permeability, overproduction of reactive oxygen species (ROS), reduction of acrosome integrity, impairment of mitochondrial membrane potential and lower sperm motility in bull [15-19], buffalo [20-22], buck [23-25], ram [26-30] and red deer [31]. Molecular studies during sperm cryopreservation offer the possibility of recognizing those specific elements (proteins, lipids, ions, carbohydrates, etc.) altered by the freezing-thawing process that are in part responsible for the structural and functional changes observed in cryopreserved sperm (Figure 1).

In this sense, understanding the molecular modifications inflicted by the freezing-thawing process is essential to diminish or prevent cryodamage. Owing to the reduced [32], if not seemingly absent, $[33,34]$ transcriptional and translational activity in mature sperm, proteomics studies represent the best option for investigating the molecular mechanisms regulating sperm functionality [35]. Moreover, it is also important to study the impact of cryopreservation on sperm RNAs transcripts since some of them are delivered to the oocyte participating in fertilization and embryo development, while others are involved in capacitation, motility, metabolism and other relevant sperm functions [36]. 


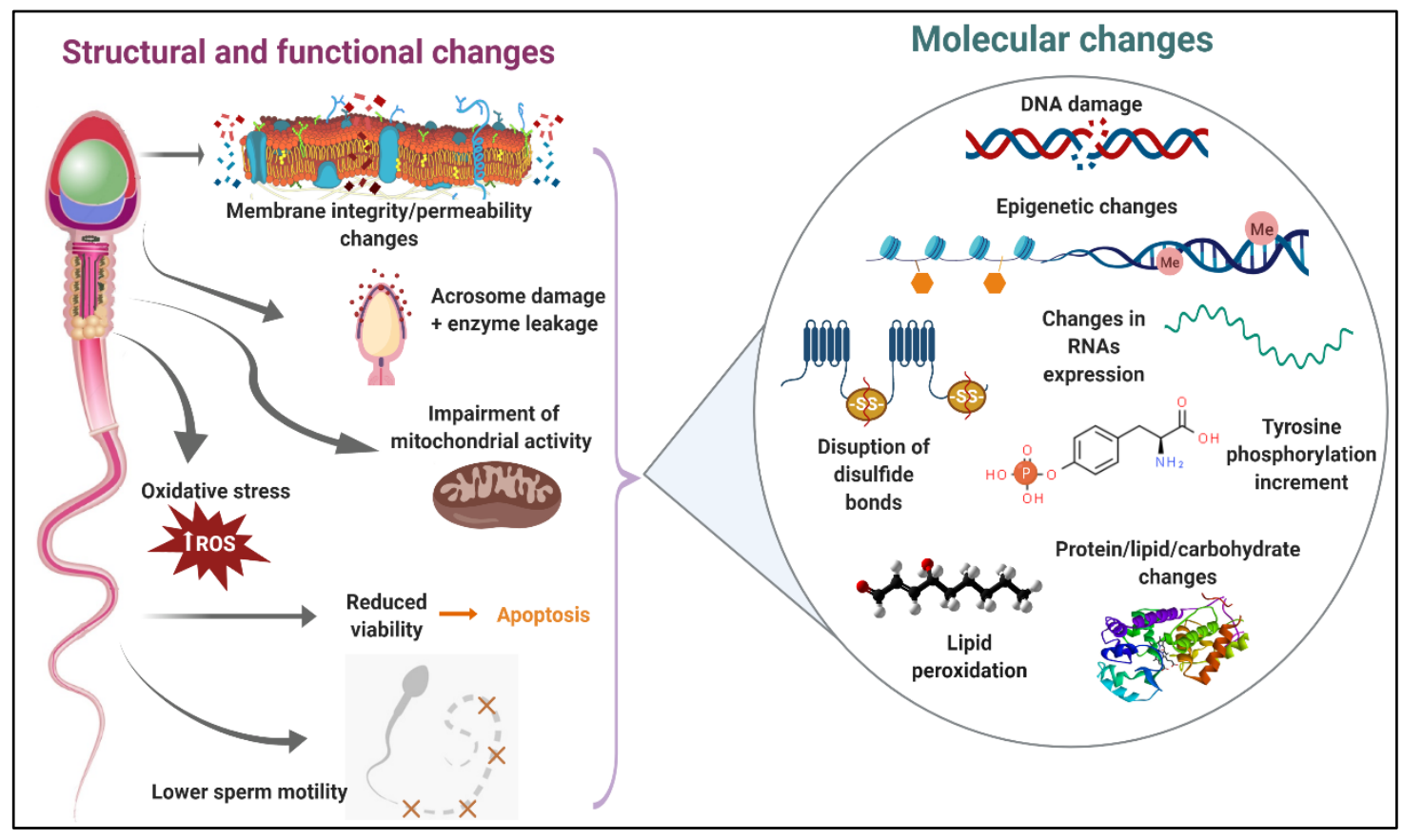

Figure 1. Main consequences of sperm cryodamage in ruminants. During the cryopreservation process, ruminant sperm suffer several structural and functional damages, which are probably the result of different molecular changes. This figure summarizes those structural, functional and molecular changes produced during the freezing-thawing procedure.

\subsection{Molecular Changes in the Sperm Plasma Membrane during Cryopreservation}

One of the first structures affected by cryopreservation is the sperm plasma membrane [2]. In ruminants, the sperm plasma membrane contains high levels of unsaturated phospholipids and low levels of cholesterol. Such composition, particularly the lower content of cholesterol, declines the resistance of sperm to the freezing-thawing process [37]. During freezing, phospholipids undergo a redistribution across the membrane, and some of them change from liquid to gel state earlier than others due to structural differences, resulting in a lipid phase separation [8]. In consequence, the lipid-protein interactions required for a proper membrane activity are disturbed [9], and some sperm surface proteins as well as membrane proteins are lost or translocated with the consequent loss of their function. For example, proteins involved in capacitation, sperm-oocyte interaction and gamete fusion, such as TCP1, LOC101123268, RPN1, P25b, HEXB, CSNK1G2, ICA, LOC101123216, ADAM2 and TIMP-2, decreased in abundance in ram, gazelle and bull sperm after cryopreservation [38-41], while another protein associated with fertilization, HSP70, was lost in buffalo sperm [42]. Other proteins involved in transport, membrane stabilization and protection against lipid peroxidation or cold-shock, such as GLUT, CLU, BSP5, BSP1, aSFP, HSPA4L, TRAP1, GPX4 and GPX5 also decreased in abundance in these species along with antiapoptotic and decapacitating proteins (CSNK2A2 and Spermadhesin Z13) $[38,40,43,44]$.

Cryopreservation also induces significant changes in the distribution or abundance of those proteins that act as ROS scavengers. Relevant antioxidant enzymes such as glutathione peroxidase (GPx), glutathione reductase (GR) and superoxide dismutase (SOD) were redistributed on ram sperm surface following cryopreservation [45]. These findings, together with the reduced antioxidant activity of SOD and reduced glutathione (GSH) observed in bull and ram sperm after cryopreservation, could explain in part the increased susceptibility of frozen-thawed sperm to suffer lipid peroxidation and oxidative damage $[45,46]$. Conversely, other studies showed that antioxidant enzymes such as SOD2 and PRDX5 increased after cryopreservation in bull sperm [44,47,48]. Whether this increment is the result of a protein reorganization like in ram sperm, or, on the contrary, if it really reflects a higher activity of these enzymes to protect sperm against oxidative attack, needs to be further verified. 
The antioxidant defense of sperm is quite scarce and basically depends on the antioxidant capacity of seminal plasma [49]. Seminal plasma contains enzymatic (GPx, SOD and CAT) and non-enzymatic antioxidants (GSH, pyruvate, urate, ascorbic acid, $\alpha$-tocopherol, taurine and hypotaurine); however, its protective effect against oxidative stress significantly decreases when semen is diluted in the freezing medium prior to cryopreservation [46].

Disturbances in the sperm antioxidant system during cryopreservation and the activation of L-Amino acid oxidase in dead or defective cryopreserved sperm significantly contribute to the increased ROS production detected in ruminant sperm after freezing-thawing, the sperm plasma membrane being the primary site where ROS-induced damage is manifested (Figure 2) $[3,17,28,50]$. Excessive generation of ROS during cryopreservation leads to major protein, lipid and carbohydrate changes in the sperm membrane due to the reduction of disulfide bonds between membrane proteins [51], peroxidation of membrane phospholipids and modifications of the sperm glycocalyx [12]. Ruminant sperm are particularly susceptible to suffer lipid peroxidation due to the higher content of polyunsaturated phospholipids in the plasma membrane [2]. Overproduction of ROS triggers the oxidative attack of polyunsaturated phospholipids, resulting in the formation of malondialdehyde (MDA), 4-hydroxynonenal (4HNE), acrolein and other toxic byproducts which may attack other polyunsaturated phospholipids $[49,50]$. As a consequence of this peroxidative damage, some cholesterol, phosphatidylethanolamine and phosphatidylcholine molecules are released [12]. This lipid peroxidative attack, together with the conformational changes that the plasma membrane experience during cryopreservation, have a negative impact on membrane integrity, destroying its semipermeable properties $[1,15,18]$.

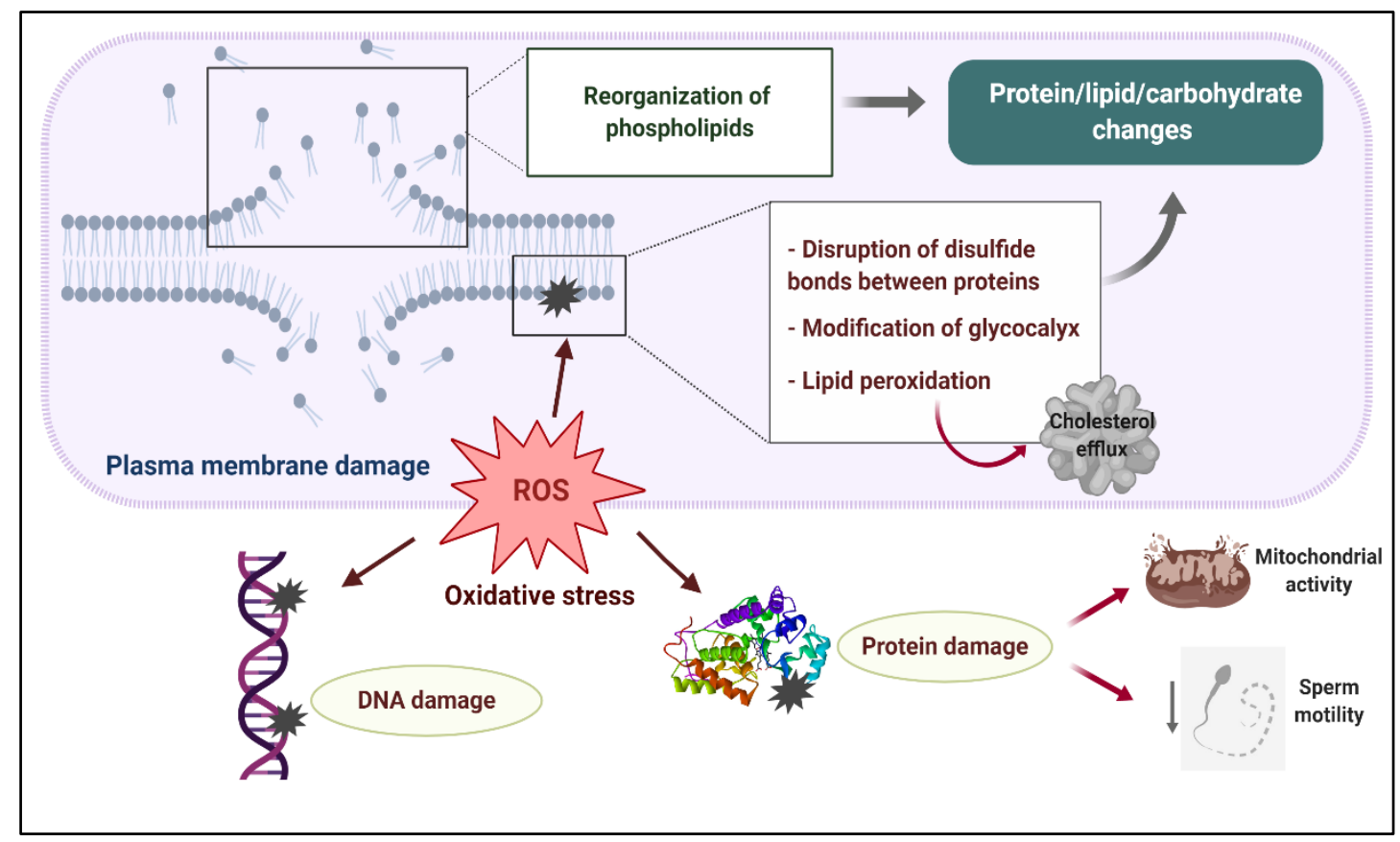

Figure 2. Plasma membrane damage during sperm cryopreservation and its relationship with oxidative stress. A reorganization of sperm membrane phospholipids takes places during freezing-thawing, altering lipid-protein, lipid-carbohydrate and protein-carbohydrate interactions which are necessary for proper membrane activity. Excessive production of reactive oxygen species (ROS) leads to major protein, lipid and carbohydrate changes in the sperm membrane due to the reduction of disulfide bonds between membrane proteins, peroxidation of membrane phospholipids and modifications of the sperm glycocalyx. As a result, the sperm membrane becomes fragile and its semipermeable property is lost. Overproduction of ROS during sperm cryopreservation may also cause DNA damage and impair several axonemal and mitochondrial proteins, which negatively affect mitochondrial activity and axonemal integrity, resulting in the loss of sperm motility. 


\subsection{Molecular Disturbances in Sperm Energy Metabolism and Motility during Cryopreservation}

During sperm cryopreservation, the consequences of oxidative damage are numerous. Besides sperm membrane damage, oxidative stress disrupts mitochondrial activity, promotes the efflux of intracellular enzymes and impairs several axonemal proteins with the consequent loss of sperm motility [52]. Lipid peroxidation derivatives, such as $4 \mathrm{HNE}$ and MDA, can diffuse into other cellular compartments and bind to protein nucleophiles, forming adducted proteins [12,50]. Adduct formation decreases and even disrupts protein function after altering protein structure. Aitken et al. [53] showed that axonemal proteins, such as dyneins, tubulins and heat-shock proteins, as well as mitochondrial proteins, like succinate dehydrogenase and ATP synthases, are common targets of these lipid peroxides. Protein adduction in the first case disturbs cytoskeleton structure, while in the second case it adversely affects the activity of electron transport chain. The electron transport chain is an essential component of mitochondrial oxidative phosphorylation involved in ATP production. Consequently, disturbances in the electron transport chain due to protein adduction lead to ATP depletion and a self-perpetuating cycle of ROS production that eventually initiates the apoptotic cascade [50]. Mostek et al. [54] reported that several proteins involved in cytoskeletal organization (Ropporin-1 (ROPN1), outer dense fiber protein 2 (ODF2), capping protein beta3 isoform, actin-related protein T2 (ACTRT2), actin-related protein M1) and energy metabolism (NADH dehydrogenase, isocitrate dehydrogenase, triosephosphate isomerase) underwent oxidative modifications via carbonylation during cryopreservation in bull sperm. However, more studies are needed to better understand the role of protein carbonylation in sperm function.

In ruminants, two main metabolic pathways, oxidative phosphorylation and glycolysis, produce the energy required to maintain sperm motility in the form of ATP [55]. Comparative proteomics studies between fresh and cryopreserved sperm revealed that freezing-thawing procedures alter the abundance of several enzymes implicated in oxidative phosphorylation and glycolysis in ram, bull and gazelle sperm $[38,43,44,47]$. Among them, different ATP synthases, COX5B, AK1, NDUFV2, ODPB2, ACO2 and NDPK7 were some of those proteins related to oxidative phosphorylation, while different hexokinases, GPI, ALDOA, GAPDH5, PGK2, PGAM2, PKM2 and TPI were some of those proteins related to glycolysis. Although the cause of these proteomics variations is yet to be resolved, some authors proposed diverse mechanisms to explain such differences, which include protein degradation, oxidation, tyrosine phosphorylation and translocation [44,54]. Modifications of mitochondrial and glycolytic proteins during cryopreservation could be in part responsible for the reduced motility of frozen-thawed sperm due to the lack of ATP production. Diverse studies demonstrated that the loss of sperm motility during freezing-thawing was associated with the impairment of mitochondrial activity [19,21,22], and a similar relationship between glycolysis and sperm motility was also suggested $[38,43]$.

Besides the negative effect of sperm cryopreservation on metabolic enzymes, cytoskeletal proteins are temperature-sensitive. This fact explains why some cytoskeletal proteins decrease in abundance (TEKT4, ODF2, ROPN1, ACTRT2, ACTL7B and actin) or change their distribution (F-actin, actin and $\beta$-dystrobrevin) during freezing-thawing in bull, ram, gazelle and buffalo sperm $[38,43,47,48,56,57]$. Such findings have significant repercussions on sperm motility since cytoskeletal proteins are involved in the maintenance of axoneme integrity. In addition, another protein (HSP90) localized in the flagellum and related to sperm structure and ATP metabolism also decrease in abundance during cryopreservation [58]. Consequently, the reduced motility of cryopreserved sperm is probably the result of both axonemal protein damage and alterations in energy availability due to enzyme modifications.

\subsection{Molecular Changes in the Sperm Chromatin during Cryopreservation}

Sperm with damaged DNA can complete the fertilization process; however, embryo development can be seriously interrupted or altered once the embryo genome is activated at the 4- or 8-cell stage due to the transcription of damaged paternal genes $[59,60]$. Contradictory results have been found regarding the effect of cryopreservation on sperm DNA integrity. While some authors reported that cryopreservation impaired sperm DNA integrity $[15,16,61]$, others reported that it 
was unaffected immediately after thawing but that significant DNA damage appeared during the subsequent incubation [29,62-64]. Although the mechanisms involved in sperm DNA damage are yet unclear, oxidative and mechanical stress appear to be the main causes during cryopreservation $[16,65]$.

A number of tests are currently available to evaluate sperm DNA fragmentation in ruminants. These include the Sperm Chromatin Structure Assay (SCSA), the terminal deoxynucleotidyl transferase dUTP Nick End Labeling assay (TUNEL), the Sperm Chromatin Dispersion (SCD) (or variants), the Comet assay and the toluidine blue stain $[11,15,66-70]$. Different studies suggest that the extent of sperm DNA damage depends on the evaluation method. Khalil et al. [15] found a higher proportion of cryopreserved bull sperm showing DNA damage with the Sperm Chromatin Structure Assay (SCSA) compared to toluidine blue staining. Peris-Frau et al. [71] compared the ability of SCSA and a variant of the Sperm Chromatin Dispersion test (SCD) to evaluate sperm DNA damage, but only the latter method detected a higher proportion of cryopreserved ram sperm showing DNA damage after $180 \mathrm{~min}$ of incubation. These findings could indicate that the diverse methods used to assess chromatin integrity provide different information about chromatin damage. For this reason and given the complexity of sperm chromatin, more than one method should be employed to assess sperm chromatin damage during different stressful conditions, such as freezing-thawing.

Several coding and non-coding RNAs, nuclear proteins and other epigenetics marks from sperm are delivered to the offspring together with the paternal genome [72]. In consequence, aside from DNA damage, changes in the relative abundance of RNAs, aberrant DNA methylation, abnormal histone modifications or improper chromatin compaction in sperm due to alterations in the nucleoprotein structure could have a severe impact on fertilization or embryogenesis $[59,73,74]$. While the effect of freezing-thawing on sperm DNA stability has been widely investigated, few studies in ruminants explored the influence of freezing-thawing on sperm epigenome. Messenger RNA (mRNA) carries the genetic code to translate proteins, but there are other RNAs termed non-coding RNAs (ncRNAs) that do not code for proteins. Both types of RNAs (mRNA and ncRNAs) have been found to modulate a variety of biological functions in sperm [36]. In addition, some ncRNAs are also involved in epigenetic regulation [75]. In consequence, variations in RNA transcripts during cryopreservation could adversely affect sperm integrity, functionality and its fertilizing potential or make the sperm vulnerable to epigenetic errors. Chen et al. [76] reported that cryopreservation modified in bull sperm the relative abundance of four ncRNAs involved in embryo development. More studies conducted in non-ruminant species revealed that cryopreservation induces diverse epigenetic changes. In horses, sperm cryopreservation increased global DNA methylation [77], whereas in boar sperm, freezing-thawing decreased the relative abundance of mRNAs as well as the protein levels of some genes associated with DNA methylation (DNMT3A, DNMT3B), histone modifications (JHDM2A, KAT8) and genomic imprinting (IGF2) [78]. Recently, a comparative transcriptome analysis of embryos obtained with fresh and cryopreserved stallion sperm revealed that several sperm mRNA transcripts with a relevant function in early embryo development were downregulated after cryopreservation [79]. However, there is a lack of similar studies in ruminant species. This clearly warrants further investigation and even deeper transcriptomics analyses between fresh and cryopreserved sperm using recent advances in transcriptome amplification and next-generation sequencing, which would improve our knowledge about the molecular mechanisms involved in sperm cryodamage.

\section{Molecular Mechanisms Involved in Those Factors That May Affect Sperm Cryotolerance}

It is well known that seasonal variations can alter the resistance of sperm to the freezing-thawing process in some species, known as sperm cryotolerance. Warmer seasons, specially summer, negatively affect the fertility rate of many ruminants due to the detrimental effect of heat stress on the female and male reproductive tract [80-82]. Moreover, since small ruminants are seasonal breeding animals, a more marked seasonality pattern has been found in these species compared to large ruminants, which is more evident in wild species than in domestics [83]. Martínez-Fresneda et al. [84] suggested that the seasonal fluctuations in sperm cryotolerance could be associated with changes in the membrane composition of 
sperm, occurring during spermatogenesis as a result of variations in the proliferative activity of germ cells and Sertoli cells among seasons. In line with this hypothesis, earlier studies found seasonal changes in the phospholipid, cholesterol and protein content of sperm [85,86]. Moreover, Westfalewicz et al. [86] reported that the majority of proteins that underwent changes in abundance during seasons came from seminal plasma. Several seminal plasma components, including diverse proteins, interact with sperm and become attached to the sperm surface after ejaculation, protecting the sperm membrane from cryodamage [87]. Those seminal plasma proteins whose abundance increased during the breeding season, were mainly involved in lipid metabolism regulation (ALB and CLU; bull sperm [86]), prevention of premature capacitation (SPZ1 and PLA2G7; bull sperm [86]) and protection against cold shock (RSVP14, RSVP20 and protein $>10 \mathrm{kDa}$ component; ram sperm $[88,89]$ ).

Other studies conducted in bull, ram and buck revealed that quantitative variations in seminal plasma and sperm proteins also appeared between males [90-96], which could explain in part the individual variability observed in sperm freezability $[97,98]$. Males are frequently categorized as good or bad freezers depending on their post-thaw sperm quality; however, molecular biomarkers could predict more efficiently sperm cryotolerance before freezing-thawing in different individuals [10]. Several proteins have been identified as potential freezability biomarkers in different ruminant species. Among them, proteins involved in energy metabolism, motility regulation and sperm membrane protection increased in abundance in males classified as good freezers (Table 1). These changes could explain the greater sperm viability, mitochondrial activity and motility of good freezers compared to bad freezers [90-95,99-101]. In this context, freezability biomarkers can be a useful tool to select those males with a superior sperm freezing resilience. But additional studies using recent advances in mass spectrometry technologies are required to identify a greater number of proteins that can be used as freezability biomarkers for a further accurate classification into good or bad freezers, especially in those ruminant species where studies are scarce. Moreover, a better characterization of all these proteins associated with sperm freezability differences would also aid in detecting proteins with a cryoprotective effect that could be incorporated into the freezing medium for enhancing sperm cryopreservation outcomes. Apart from variations in protein content, single nucleotide polymorphisms in different genes (e.g., HSP70 in buck sperm, PRNT in ram sperm and CFTR in bull sperm) have been correlated with inter-individual differences in sperm freezability [102-104]. Whether these genetic variations are the reason for the different protein profile of good and bad freezers still need to be elucidated. 
Table 1. Proteins that can be used as biomarkers to predict sperm freezability in ruminants due to their higher abundance in good freezers (GF) compared to bad freezers $(\mathrm{BF})$.

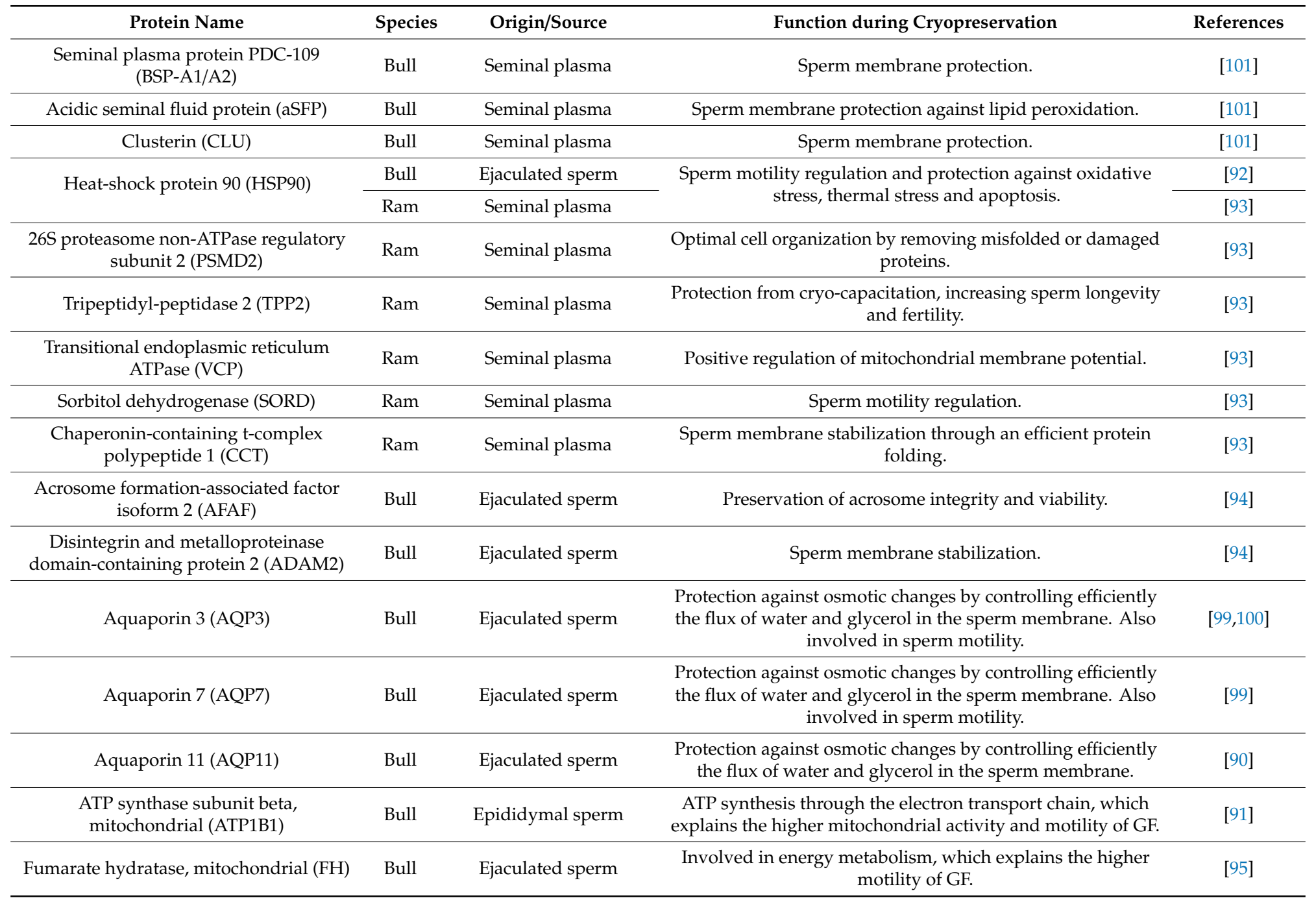


On the other hand, it is widely known that different sperm subpopulations with distinct kinematic, functional and morphometric characteristics coexist in the ejaculates [105-107], which leads to interand intra-male variations. The different steps of freezing-thawing process have been shown to alter the distribution of these kinematic and morphometric sperm subpopulations originally present in fresh ejaculates of ram, bull and buck [108-110]. These findings suggest that those fresh ejaculates with a higher subpopulation of sperm exhibiting a fast and progressive motility pattern as well as a low sperm head area could resist more the cryopreservation process. However, the molecular mechanisms underlying differences between sperm subpopulations still remain unclear during cryopreservation owing to the difficulties of analyzing separately the different sperm subpopulations present in the ejaculate with the traditional molecular approaches. A recent empirical study on bull sperm subpopulations obtained by a sperm selection procedure showed that the kinematic and functional differences between these subpopulations could be attributed to the different protein profiles detected in these subpopulations [111]. In this context, the use of computational and multiparametric flow cytometry seems to be a promising strategy to study multiple proteins simultaneously to their effects on sperm functionality at a single-cell level [112]. This approach would enhance our molecular understanding about the heterogeneous complexity of ejaculates, thereby contributing to identifying those sperm subpopulations with high cryotolerance.

Another factor that may affect sperm cryotolerance is the sperm source (epididymal or ejaculated). After ejaculation, sperm come into contact with seminal plasma, whereas epididymal sperm are exposed to epididymal fluid, whose composition differs from seminal plasma due to the lack of secretions from accessory sex glands. The interaction of sperm with a different surrounding medium seems to be the reason for such differences, resulting in changes in the lipid-protein composition of the plasma membrane, which in turn alters membrane stability and, ultimately, the sperm's ability to withstand cryopreservation $[113,114]$. A comparative proteomics analysis in fresh ram sperm revealed that three proteins (EDIL3, BSP5 and LEG1) from seminal plasma were only present in ejaculated sperm but not in epididymal sperm, whereas four membrane proteins (SPADH2, PPP1R7, BDH2 and RNASE9) were more abundant in ejaculated than epididymal sperm due to their higher concentration in the seminal plasma [115]. However, the role of these proteins in the reproductive and cryopreservation process still needs to be further characterized. Recently, a deeper proteomics study on a non-ruminant species (boar) showed intriguing results about how variations in the proteome of epididymal and ejaculated sperm could affect the sperm cryotolerance [116]. Many of the differentially abundant proteins between these sperm sources were mainly involved in energy metabolism, structural activity, redox homeostasis, immune response and fertilization. Although some proteins from seminal plasma are able to prevent or revert the cold-shock damage on sperm [87,117], other proteins from seminal plasma have been negatively correlated with sperm preservation ability [118]. For example, binder of sperm proteins (BSP), which are one of the most abundant protein families in bull and ram seminal plasma, exert a different effect during cryopreservation in these species. In bull, BSP proteins promote sperm capacitation and have a beneficial role in sperm function but, at the same time, stimulate cholesterol and phospholipid efflux from the sperm plasma membrane [119]. Cholesterol molecules provide rigidity and stability to the sperm membrane. In consequence, the release of cholesterol molecules from the sperm membrane due to the action of BSP proteins decreases the sperm freezing resilience, which is detrimental to post-thaw sperm quality [119]. However, in ram sperm, these proteins had beneficial effects on post-thaw sperm quality, protecting ram sperm from cryodamage [120]. Clearly, further proteomics studies in different ruminant species are required to find out those proteins responsible for the differences found between epididymal and ejaculated sperm cryotolerance in each species.

\section{Molecular Aspects of Those Novel Strategies to Reduce Sperm Cryodamage}

Currently, there is a wide variety of extenders that can be used during sperm cryopreservation in different ruminant species (reviewed by [7,11,121-124]); however, not all of them offer the same protection against sperm cryodamage. Therefore, sperm cryotolerance and post-thaw sperm quality 
can be affected by the type of cryoprotectants, antioxidants and other components incorporated into the freezing medium as well as by their concentration $[11,31,125]$. Extenders usually contain various components (buffers, antibiotics, sugars, fatty acids, cryoprotectants, antioxidants and other substances) to efficiently protect sperm viability and fertility during cryopreservation [123]. Cryoprotectants protect sperm from ice crystal formation, osmotic and chemical stress. Such components can be classified into permeating and non-permeating, and both types of cryoprotectants are usually included in the extenders. Glycerol is the permeating cryoprotectant most commonly used in ruminants during sperm cryopreservation, while egg yolk is the non-permeating cryoprotectant. The former is cytotoxic beyond certain concentration and has been shown to alter in bull sperm some proteins associated with sperm-oocyte binding (IZUMO4), energy metabolism (PDB1, NUDFV2, NDPK7), cytoskeleton organization (CAPZB, ODF2) and ROS metabolism (SOD2), which may negatively affect sperm function [48]. For this reason, the combination of glycerol with non-permeating cryoprotectants (egg yolk, fructose, sucrose or trehalose) seems to be the best alternative to reduce glycerol concentration and its side effects in red deer [126], buffalo [127], bull [128], buck [129] and ram sperm [130]. Recently, a novel cryoprotective agent, carboxylated poly-L-lysine, has been used to reduce glycerol concentration in the freezing medium, enhancing in vivo fertility of cryopreserved buffalo and bull sperm [131,132]. Regarding non-permeating cryoprotectants, it has been reported that egg yolk also alters the proteome of ram sperm before cryopreservation [40]. Therefore, special attention should be payed to sperm-cryoprotectant interactions since these interactions may affect sperm cryopreservation outcomes. Additional studies should be conducted to elucidate whether glycerol and egg yolk exert the same impact on the sperm proteome of other ruminant species.

Another strategy for protecting sperm against cryodamage is the increment of the cholesterol membrane content prior to cryopreservation by adding cholesterol-loaded cyclodextrins (CLC) to the freezing medium. This treatment improves sperm membrane stability after incorporating exogenous cholesterol to the plasma membrane, which in turn enhances sperm cryosurvival, motility, mitochondrial activity and the number of sperm attached to zona pellucida, reducing at the same time cryo-capacitation and premature tyrosine phosphorylation [133-136]. The beneficial effects of CLC seem to be greater in those ejaculates with low freezability, at least in ram sperm [137]. Moreover, the addition of CLC to the extender attenuated in gazelle sperm the degradation of three proteins related to energy metabolism and cytoskeletal organization (CAPZB, HSP90A, PAGM2) during the freezing-thawing process compared to untreated sperm, which may explain the increased motility observed in CLC treated sperm [38]. Notwithstanding, the effectiveness of this strategy differs between studies and also among ruminant species, possibly because the optimal concentration still needs to be determined.

Supplementation of the freezing medium with antioxidants reduces the negative effects generated by the excessive ROS production during cryopreservation, which improves sperm cryosurvival. Antioxidants can be classified into enzymatic and non-enzymatic, and both types can be added to the freezing medium, yielding different results $[5,138]$. The former includes superoxide dismutase (SOD), glutathione reductase (GR), glutathione peroxidase (GPx) and catalase (CAT), while the latter includes reduced glutathione (GSH), vitamins, plant extracts (e.g., cinnamtannin B-1), minerals, amino acids, proteins and other exogenous compounds (e.g., resveratrol or quercetin) with antioxidant properties $[123,139]$. Recent studies investigated the addition of different nanoparticles to the freezing medium to overcome the main drawbacks that conventional antioxidants could present, like the low durability to harsh conditions [140-143]. Nanotechnology advances have contributed to the design of novel nano-compounds that possess antioxidant properties, such as selenium, zinc oxide and apoferritin containing gold-silver nanoparticles. Addition of selenium nanoparticles to semen extender enhanced viability, motility and chromatin integrity of cryopreserved bull sperm, obtaining greater in vivo fertility results [140]. Similar results were reported in cryopreserved ram sperm when selenium particles were added to the freezing medium [141]. These findings can be explained by the positive effect that selenium nanoparticles exert on GPx activity, reducing oxidative stress, lipid 
peroxidation and apoptosis. Supplementation of the freezing medium with selenium or zinc oxide nanoparticles also improved the post-thaw quality of dromedary camel sperm [142]. Both nanoparticles have the ability to enhance the activity of antioxidant enzymes (GPx and SOD), GSH and scavenge ROS. Such properties improved viability, membrane integrity and motility of cryopreserved sperm while decreasing apoptosis. Another nanoparticle recently designed to mimic SOD, CAT and GPx activity consisted in a silver-gold nanohybrid in apoferritin cage [143]. Enrichment of semen extender with apoferritin containing gold-silver nanoparticles resulted in a greater sperm viability and motility after thawing due to the reduction of ROS levels and apoptosis during cryopreservation. These studies reaffirm the potential of nanoparticles to protect sperm from oxidative damage during freezing-thawing, but further investigations should be performed in different ruminant species to avoid nanotoxicity on sperm cells.

Melatonin is another potential candidate to include in the freezing medium due to its protective effect against oxidative stress, which is dose-dependent [144]. The beneficial effects of melatonin on sperm cryopreservation rely on its powerful antioxidant property and its ability to stimulate the enzymatic activity of SOD, GPx and CAT [145]. A recent study in ram showed that melatonin improves mitochondrial oxidative phosphorylation of frozen-thawed sperm by suppressing mitochondrial permeability transition pore (MPTP) opening [146]. MPTP is a multi-component protein aggregate in mitochondria that has two main functions: regulation of oxidative phosphorylation for energy synthesis and induction of cell death when converted into a non-specific channel. When this complex is open, mitochondrial function declines and the apoptosis-inducing factor as well as some pro-apoptotic factors, such as cytochrome c, are released, initiating apoptosis [147]. Addition of melatonin to the freezing medium prevents a prolonged opening of MPTP during cryopreservation, which in turn increases ATP production, improving post-thaw sperm motility [146].

Proteomics studies on seminal plasma have greatly contributed to identifying those proteins with beneficial effects on sperm cryopreservation, facilitating the generation of recombinant proteins as a promising strategy for sperm cryopreservation. Recently, supplementation of the extender with recombinant seminal plasma proteins such as regucalcin (RGN), a recombinant peptide containing four FNII domains (TrxA-FNIIx4-His 6 ) and serine protease inhibitor kazal-type 3 (SPINK3) have been shown to exert a cryoprotective effect on sperm [148-150]. A greater number of cryopreserved buffalo sperm were attached to zona pellucida when the freezing medium was supplemented with the recombinant RGN due to its positive effect on post-thaw sperm motility and acrosome integrity [148]. The beneficial effects of RGN may rely on its calcium-regulating and antioxidant functions. In frozen-thawed ram sperm, TrxA-FNIIx4-His 6 has been shown to reduce cryo-capacitation, enhancing in vitro fertilization rates [149]. Another protein from seminal plasma that prevents and reverts cryo-capacitation is SPINK3. Zalazar et al. [150] reported that addition of heterologous SPINK3 before or after freezing-thawing decreased protein tyrosine phosphorylation and intracellular calcium influx in ram sperm. However, other sperm parameters related to sperm quality and fertility only improved when this recombinant protein was added after cryopreservation, probably due to the interaction of SPINK3 with extender components such as egg yolk before freezing, which may alter the ability of this protein to reduce sperm cryodamage [151].

Antifreeze proteins and glycoproteins are other cryoprotective elements that deserve special attention. These proteins, which are produced by some insects, Antarctic fishes, crustaceans, bacteria, fungi and microalgae, have the capacity to protect sperm membrane from cryodamage by preventing ice crystal formation [152]. Addition of antifreeze protein and glycoprotein type I to semen extender significantly increased post-thaw motility in ram sperm [153], whereas in bull, supplementation with antifreeze protein type I only improved the osmotic resistance of sperm during cryopreservation [154]. In buffalo, different studies showed that an antifreeze protein type III, two antifreeze glycoproteins and a recombinant antifreeze protein from beetle Dendroides canadensis enhanced sperm membrane integrity and motility after thawing when added to the freezing medium prior to cryopreservation [155-157]. 
Another alternative to avoid ice crystal formation during conventional freezing procedures includes vitrification. This simple and cost-effective technique involves a short pre-freezing equilibration and an ultra-rapid cooling rate using different buffer systems and concentrations of cryoprotectants for each species due to species-specific characteristics [3]. Arando et al. [158] reported that a short equilibration period at $5{ }^{\circ} \mathrm{C}$ before vitrification and dilution of ram sperm with a freezing extender containing sucrose improved post-thaw viability and motility, although these parameters were lower than in fresh samples. Another study in ram sperm showed that vitrification with egg yolk and glycerol at the lowest sperm concentration gave acceptable results in terms of viability and acrosome integrity in comparison to sperm vitrified with sucrose and glycerol [159]. However, vitrified ram sperm had a lower quality than sperm cryopreserved by conventional method. A similar situation was reported in mouflon sperm vitrified with sucrose [160]. On the contrary, vitrification of Iberian Ibex (Capra pyrenaica) sperm yielded a similar post-thaw quality and in vitro fertilization rate than sperm cryopreserved by conventional method [161]. Although major improvements are needed, vitrification could be extremely useful for preserving wild and endangered ruminant species under field conditions since sophisticated equipment is not required and the technique is relatively fast.

\section{Concluding Remarks and Future Directions}

Cryopreservation alters a variety of proteins and ARNs transcripts involved in relevant sperm functions, such as sperm motility, capacitation, fertilization and embryo development. Understanding the molecular damages caused by the freezing-thawing process is fundamental to protect these molecular elements and prevent or reduce those changes in sperm structure or function that negatively affect the reproductive performance. This is particularly relevant in ruminants since the majority of these species are more prone to suffer greater sperm cryodamage, requiring major improvements in the freezing-thawing process to obtain fertilization rates comparable to fresh sperm.

Advances in proteomics, transcriptomics and epigenomics technologies have provided new insights into the mechanisms underlying sperm cryodamage and those factors affecting sperm cryotolerance. This valuable information, which has been widely described in this review, is essential for the detection of potential biomarkers to predict more accurately sperm freezability as well as for the development of new strategies to enhance sperm cryopreservation outcomes. However, several challenges still need to be resolved. To address these issues, future studies on sperm cryopreservation should combine multiple technologies to investigate changes in sperm protein levels and location simultaneously to their effects on sperm functionality. In this sense, it would be interesting to combine high-throughput mass spectrometry with multiparametric, computational and imaging flow cytometry. The combination of these powerful technologies would offer a deeper insight into the molecular and cellular changes induced by the freezing-thawing process, facilitating data interpretation to improve sperm functionality and fertility of cryopreserved samples in different ruminant species. In addition, further transcriptomics and epigenomics studies are also required to increase our knowledge about how sperm cryopreservation affect different RNA transcripts and epigenetic-related genes involved in fertilization and embryo development in ruminant species.

On the other hand, supplementation of the freezing medium with novel cryoprotectants, antioxidants and other new components such as proteins or nanoparticles requires a further optimization to be an effective alternative to the commercial extenders currently used for cryopreservation of ruminant sperm. Therefore, further investigations with a wider range of concentrations, combinations of various novel cryoprotectants, antioxidants and proteins, and validation of post-thaw sperm fertility are needed.

Author Contributions: P.P.-F., writing-original draft preparation, P.P.-F., A.J.S., M.I.-C., A.M.-M. (Alicia Martín-Maestro), I.S.-A., D.A.M.-C., M.R.F.-S., O.G.-Á., A.M.-M. (Alejandro Maroto-Morales), V.M., J.J.G., review and editing the manuscript; J.J.G., A.J.S. and M.R.F.-S., funding acquisition. All authors have read and agreed to the published version of the manuscript. 
Funding: Spanish Ministry of Economy and Competitiveness (AGL2016-81905-REDT). MIC and AMM were supported by a Ministry of Economy and Competitiveness scholarship and PPF was supported by a University of Castilla-La Mancha scholarship.

Conflicts of Interest: The authors declare no conflict of interest.

\section{Abbreviations}

\begin{tabular}{|c|c|}
\hline TCP1 & T-complex protein 1 subunit alpha \\
\hline LOC101123268 & Dolichyl-diphosphooligosaccharide-protein glycosyltransferase \\
\hline RPN1 & Dolichyl-diphosphooligosaccharide-protein glycosyltransferase subunit 1 \\
\hline HEXB & Beta-hexosaminidase subunit beta-like isoform $\mathrm{X} 1$ \\
\hline CSNK1G2 & Casein kinase I isoform gamma-2 isoform X2 \\
\hline ICA & Inhibitor of carbonic anhydrase-like isoform X3 \\
\hline LOC101123216 & Disintegrin and metalloproteinase domain-containing protein 20 \\
\hline ADAM2 & Fertilin beta \\
\hline TIMP-2 & Tissue inhibitor of metalloproteinases 2 \\
\hline HSP70 & Heat shock $70 \mathrm{kDa}$ protein \\
\hline GLUT & Glucose transporter \\
\hline CLU & Clusterin \\
\hline BSP5 & Binder of sperm protein 5 \\
\hline BSP1 & Binder of sperm protein 1 \\
\hline aSFP & Acidic seminal fluid protein \\
\hline HSP4AL & Heat shock $70 \mathrm{kDa}$ protein $4 \mathrm{~L}$ isoform $\mathrm{C} 1$ \\
\hline TRAP1 & Heat shock protein $75 \mathrm{kDa}$, mitochondrial isoform $\mathrm{X} 3$ \\
\hline GPX4 & Phospholipid hydroperoxide glutathione peroxidase \\
\hline GPX5 & Epididymal secretory glutathione peroxidase \\
\hline CSNK2A2 & Casein kinase II subunit alpha \\
\hline SOD2 & Superoxide dismutase 2 \\
\hline PRDX5 & Peroxiredoxin 5 \\
\hline COX5B & Cytochrome c oxidase subunit $5 \mathrm{~B}$, mitochondrial \\
\hline AK1 & Adenylate kinase isoenzyme 1 \\
\hline NUDFV2 & NADH dehydrogenase flavoprotein 2 \\
\hline ODPB2 & Pyruvate dehydrogenase E1 component subunit beta, mitochondrial isoform 2 \\
\hline $\mathrm{ACO} 2$ & Aconitate hydratase, mitochondrial \\
\hline NDPK7 & Nucleoside diphosphate kinase 7 \\
\hline GPI & Glucose-6-phosphate isomerase \\
\hline ALDOA & Fructose-bisphosphate aldolase \\
\hline GAPDH5 & Glyceraldehyde-3-phosphate dehydrogenase, testis-specific \\
\hline PGK2 & Phosphoglycerate kinase 2 \\
\hline PGAM2 & Phosphoglycerate mutase 2 \\
\hline PKM2 & Pyruvate kinase M2 \\
\hline TPI & Triosephosphate isomerase \\
\hline TEKT4 & Tektin 4 \\
\hline ACTL7B & Actin-like protein 7B \\
\hline HSP90 & Heat shock $90 \mathrm{kDa}$ protein \\
\hline DNMT3A & DNA (cytosine-5-)-methyltransferase 3 alpha \\
\hline DNMT3B & DNA (cytosine-5-)-methyltransferase 3 beta \\
\hline JHDM2A & JmjC domain-containing histone demethylation protein $2 \mathrm{~A}$ \\
\hline KAT8 & K(lysine) acetyltransferase 8 \\
\hline IGF2 & Insulin-like growth factor 2 \\
\hline ALB & Bovine serum albumin \\
\hline SPZ1 & Spermadhesin 1 \\
\hline PLA2G7 & Platelet-activating factor ace- tylhydrolase precursor \\
\hline RSVP14 & Ram seminal vesicle protein $14 \mathrm{kDa}$ \\
\hline RSVP20 & Ram seminal vesicle protein $20 \mathrm{kDa}$ \\
\hline
\end{tabular}




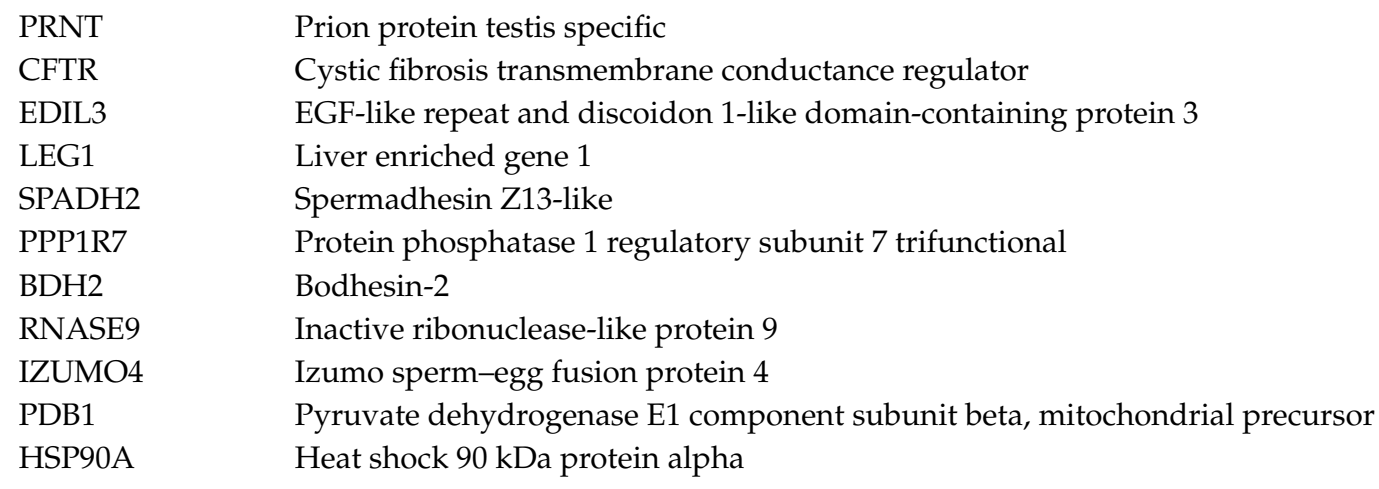

\section{References}

1. Bailey, J.; Morrier, A.; Cormier, N. Semen cryopreservation: Successes and persistent problems in farm species. Can. J. Anim. Sci. 2003, 83, 393-401. [CrossRef]

2. Bailey, J.L.; Bilodeau, J.F.; Cormier, N. Semen cryopreservation in domestic animals: A damaging and capacitating phenomenon. J. Androl. 2000, 21, 1-7.

3. Kumar, A.; Prasad, J.K.; Srivastava, N.; Ghosh, S.K. Strategies to minimize various stress-related freeze-thaw damages during conventional cryopreservation of mammalian spermatozoa. Biopreserv. Biobank. 2019, 17, 603-612. [CrossRef]

4. Ezzati, M.; Shanehbandi, D.; Hamdi, K.; Rahbar, S.; Pashaiasl, M. Influence of cryopreservation on structure and function of mammalian spermatozoa: An overview. Cell Tissue Bank. 2020, 21, 1-15. [CrossRef]

5. Amidi, F.; Pazhohan, A.; Shabani Nashtaei, M.; Khodarahmian, M.; Nekoonam, S. The role of antioxidants in sperm freezing: A review. Cell Tissue Bank. 2016, 17, 745-756. [CrossRef]

6. Watson, P.F. Recent developments and concepts in the cryopreservation of spermatozoa and the assessment of their post-thawing function. Reprod. Fertil. Dev. 1995, 7, 871-891. [CrossRef] [PubMed]

7. Lv, C.; Wu, G.; Hong, Q.; Quan, G. Spermatozoa cryopreservation: State of art and future in small ruminants. Biopreserv. Biobank. 2018, 17, 171-182. [CrossRef] [PubMed]

8. Grötter, L.G.; Cattaneo, L.; Estela, P.; Kjelland, M.E.; Ferré, L.B. Recent advances in bovine sperm cryopreservation techniques with a focus on sperm post-Thaw quality optimization. Reprod. Domest. Anim. 2019, 54, 655-665. [CrossRef] [PubMed]

9. Lemma, A. Effect of Cryopreservation on sperm quality and fertility. Artif. Insemin. Farm Anim. 2011, 191-216.

10. Yeste, M. Sperm cryopreservation update: Cryodamage, markers, and factors affecting the sperm freezability in pigs. Theriogenology 2016, 85, 47-64. [CrossRef]

11. Ugur, M.R.; Abdelrahman, A.S.; Evans, H.C.; Gilmore, A.A.; Hitit, M.; Arifiantini, R.I.; Purwantara, B.; Kaya, A.; Memili, E. Advances in cryopreservation of bull sperm. Front. Vet. Sci. 2019, 6, 268. [CrossRef]

12. Pini, T.; Leahy, T.; de Graaf, S.P. Sublethal sperm freezing damage: Manifestations and solutions. Theriogenology 2018, 118, 172-181. [CrossRef] [PubMed]

13. Hezavehei, M.; Sharafi, M.; Kouchesfahani, H.M.; Henkel, R.; Agarwal, A.; Esmaeili, V.; Shahverdi, A. Sperm cryopreservation: A review on current molecular cryobiology and advanced approaches. Reprod. Biomed. Online 2018, 37, 327-339. [CrossRef] [PubMed]

14. Pulina, G.; Helena, A.; Francesconi, D.; Stefanon, B.; Calamari, L.; Lacetera, N.; Orto, V.D.; Pilla, F.; Marsan, A.; Mele, M.; et al. Sustainable ruminant production to help feed the planet. Ital. J. Anim. Sci. 2017, 16, 140-171. [CrossRef]

15. Khalil, W.A.; El-harairy, M.A.; Zeidan, A.E.B.; Hassan, M.A.E.; Mohey-Elsaeed, O. Evaluation of bull spermatozoa during and after cryopreservation: Structural and ultrastructural insights. Int. J. Vet. Sci. Med. 2018, 6, S49-S56. [CrossRef] [PubMed]

16. Gürler, H.; Malama, E.; Heppelmann, M.; Calisici, O.; Leiding, C.; Kastelic, J.P.; Bollwein, H. Effects of cryopreservation on sperm viability, synthesis of reactive oxygen species, and DNA damage of bovine sperm. Theriogenology 2016, 86, 562-571. [CrossRef] [PubMed]

17. Chatterjee, S.; Gagnon, C. Production of reactive oxygen species by spermatozoa undergoing cooling, freezing, and thawing. Mol. Reprod. Dev. 2001, 59, 451-458. [CrossRef] 
18. Pons-Rejraji, H.; Bailey, J.L.; Leclerc, P. Cryopreservation affects bovine sperm intracellular parameters associated with capacitation and acrosome exocytosis. Reprod. Fertil. Dev. 2009, 21, 525-537. [CrossRef]

19. Yoon, S.J.; Kwon, W.S.; Rahman, M.S.; Lee, J.S.; Pang, M.G. A novel approach to identifying physical markers of cryo-damage in bull spermatozoa. PLoS ONE 2015, 10, e0126232. [CrossRef]

20. Rasul, Z.; Ahmad, N.; Anzar, M. Changes in motion characteristics, plasma membrane integrity, and acrosome morphology during cryopreservation of buffalo spermatozoa. J. Androl. 2001, 22, 278-283.

21. Kadirvel, G.; Kumar, S.; Kumaresan, A. Lipid peroxidation, mitochondrial membrane potential and DNA integrity of spermatozoa in relation to intracellular reactive oxygen species in liquid and frozen-thawed buffalo semen. Anim. Reprod. Sci. 2009, 114, 125-134. [CrossRef] [PubMed]

22. Kumar, D.; Kumar, P.; Singh, P.; Yadav, S.P.; Yadav, P.S. Assessment of sperm damages during different stages of cryopreservation in water buffalo by fluorescent probes. Cytotechnology 2016, 68, 451-458. [CrossRef] [PubMed]

23. Ahmad, M.; Nasrullah, R.; Riaz, H.; Sattar, A.; Ahmad, N. Changes in motility, morphology, plasma membrane and acrosome integrity during stages of cryopreservation of buck sperm. J. S. Afr. Vet. Assoc. 2014, 85, 1-5. [CrossRef] [PubMed]

24. Dorado, J.; Hidalgo, M.; Muñoz, A.; Rodríguez, I. Assessment of goat semen freezability according to the spermatozoa characteristics from fresh and frozen samples. Anim. Reprod. Sci. 2009, 112, 150-157. [CrossRef]

25. Chauhan, M.S.; Kapila, R.; Gandhi, K.K.; Anand, S.R. Acrosome damage and enzyme leakage of goat spermatozoa during dilution, cooling and freezing. Andrologia 1994, 26, 21-26. [CrossRef]

26. Nur, Z.; Zik, B.; Ustuner, B.; Sagirkaya, H.; Ozguden, C.G. Effects of different cryoprotective agents on ram sperm morphology and DNA integrity. Theriogenology 2010, 73, 1267-1275. [CrossRef]

27. Peris-Frau, P.; Martín-Maestro, A.; Iniesta-Cuerda, M.; Sánchez-Ajofrín, I.; Cesari, A.; Garde, J.J.; Villar, M.; Soler, A.J. Cryopreservation of ram sperm alters the dynamic changes associated with in vitro capacitation. Theriogenology 2020, 145, 100-108. [CrossRef]

28. Da Silva Maia, M.; Bicudo, S.D.; Sicherle, C.C.; Rodello, L.; Gallego, I.C.S. Lipid peroxidation and generation of hydrogen peroxide in frozen-thawed ram semen cryopreserved in extenders with antioxidants. Anim. Reprod. Sci. 2010, 122, 118-123. [CrossRef]

29. Peris, S.I.; Morrier, A.; Dufour, M.; Bailey, J.L. Cryopreservation of ram semen facilitates sperm DNA damage: Relationship between sperm andrological parameters and the sperm chromatin structure Assay. J. Androl. 2004, 25, 224-233. [CrossRef]

30. García-Álvarez, O.; Maroto-Morales, A.; Martínez-Pastor, F.; Garde, J.J.; Ramón, M.; Fernández-Santos, M.R.; Esteso, M.C.; Pérez-Guzmán, M.D.; Soler, A.J. Sperm characteristics and in vitro fertilization ability of thawed spermatozoa from black manchega ram: Electroejaculation and postmortem collection. Theriogenology 2009, 72, 160-168. [CrossRef]

31. Fernández-Santos, M.R.; Esteso, M.C.; Montoro, V.; Soler, A.J.; Garde, J.J. Cryopreservation of Iberian red deer (Cervus elaphus hispanicus) epididymal spermatozoa: Effects of egg yolk, glycerol and cooling rate. Theriogenology 2006, 66, 1931-1942. [CrossRef] [PubMed]

32. Gur, Y.; Breitbart, H. Mammalian sperm translate nuclear-encoded proteins by mitochondrial-type ribosomes. Genes Dev. 2006, 20, 411-416. [CrossRef] [PubMed]

33. Baker, M.A.; Nixon, B.; Naumovski, N.; Aitken, R.J. Proteomic insights into the maturation and capacitation of mammalian spermatozoa. Syst. Biol. Reprod. Med. 2012, 58, 211-217. [CrossRef] [PubMed]

34. Oliva, R.; De Mateo, S.; Estanyol, J.M. Sperm cell proteomics. Proteomics 2009, 9, 1004-1017. [CrossRef] [PubMed]

35. Mohanty, G.; Swain, N.; Samanta, L. Sperm proteome: What is on the horizon? Reprod. Sci. 2014, 22, 638-653. [CrossRef]

36. Dai, D.; Qazi, I.H.; Ran, M.; Liang, K.; Zhang, Y. Exploration of miRNA and mRNA profiles in fresh and frozen-thawed boar sperm by transcriptome and small RNA sequencing. Int. J. Mol. Sci. 2019, $20,802$. [CrossRef]

37. Darin-Bennett, A.; White, I.G. Influence of the cholesterol content of mammalian spermatozoa on susceptibility to cold-shock. Cryobiology 1977, 14, 466-470. [CrossRef]

38. Wojtusik, J.; Wang, Y.; Pukazhenthi, B.S. Pretreatment with cholesterol-loaded cyclodextrins prevents loss of motility associated proteins during cryopreservation of addra gazelle (Nanger dama ruficollis) spermatozoa. Cryobiology 2018, 81, 74-80. [CrossRef] 
39. Lessard, C.; Parent, S.; Leclerc, P.; Bailey, J.L.; Sullivan, R. Cryopreservation alters the levels of the bull sperm surface protein P25b. J. Androl. 2000, 21, 700-707.

40. Pini, T.; Rickard, J.P.; Leahy, T.; Crossett, B.; Druart, X.; De Graaf, S.P. Cryopreservation and egg yolk medium alter the proteome of ram spermatozoa. J. Proteom. 2018, 181, 73-82. [CrossRef]

41. Peris-Frau, P.; Martín-Maestro, A.; Iniesta-Cuerda, M.; Sánchez-Ajofrín, I.; Mateos-Hernández, L.; Garde, J.J.; Villar, M.; Soler, A.J. Freezing-Thawing procedures remodel the proteome of ram sperm before and after in vitro capacitation. Int. J. Mol. Sci. 2019, 20, 4596. [CrossRef] [PubMed]

42. Varghese, T.; Divyashree, B.C.; Roy, S.C.; Roy, K.S. Loss of heat shock protein 70 from apical region of buffalo (Bubalus bubalis) sperm head after freezing and thawing. Theriogenology 2016, 85, 828-834. [CrossRef] [PubMed]

43. He, Y.; Wang, K.; Zhao, X.; Zhang, Y.; Ma, Y.; Hu, J. Differential proteome association study of freeze-thaw damage in ram sperm. Cryobiology 2016, 72, 60-68. [CrossRef] [PubMed]

44. Westfalewicz, B.; Dietrich, M.A.; Ciereszko, A. Impact of cryopreservation on bull (Bos taurus) semen proteome. J. Anim. Sci. 2015, 93, 5240-5253. [CrossRef]

45. Marti, E.; Marti, J.I.; Muiño-Blanco, T.; Cebrián-Pérez, J.A. Effect of the cryopreservation process on the activity and immunolocalization of antioxidant enzymes in ram spermatozoa. J. Androl. 2008, 29, 459-467. [CrossRef]

46. Bilodeau, J.-F.; Chatterjee, S.; Sirard, M.A.; Gagnon, C. Levels of antioxidant defenses are decreased in bovine spermatozoa after a cycle of freezing. Mol. Hum. Reprod. 2000, 55, 282-288. [CrossRef]

47. Yoon, S.J.; Rahman, M.S.; Kwon, W.S.; Ryu, D.Y.; Park, Y.J.; Pang, M.G. Proteomic identification of cryostress in epididymal spermatozoa. J. Anim. Sci. Biotechnol. 2016, 7, 1-12. [CrossRef]

48. Yoon, S.J.; Rahman, M.S.; Kwon, W.S.; Park, Y.J.; Pang, M.G. Addition of cryoprotectant significantly alters the epididymal sperm proteome. PLoS ONE 2016, 11, e0152690. [CrossRef]

49. Martin-Hidalgo, D.; Bragado, M.J.; Batista, A.R.; Oliveira, P.F.; Alves, M.G. Antioxidants and male fertility: From molecular studies to clinical evidence. Antioxidants 2019, 8, 89. [CrossRef]

50. Aitken, R.J. Reactive oxygen species as mediators of sperm capacitation and pathological damage. Mol. Reprod. Dev. 2017, 84, 1039-1052. [CrossRef]

51. Chatterjee, S.; De Lamirande, E.; Gagnon, C. Cryopreservation alters membrane sulfhydryl status of bull spermatozoa: Protection by oxidized glutathione. Mol. Reprod. Dev. 2001, 60, 498-506. [CrossRef] [PubMed]

52. Aitken, R.J. Free radicals, lipid peroxidation and sperm function. Reprod. Fertil. Dev. 1995, 7, 659-668. [CrossRef] [PubMed]

53. Aitken, R.J.; Baker, M.A.; Nixon, B. Are sperm capacitation and apoptosis the opposite ends of a continuum driven by oxidative stress? Asian J. Androl. 2015, 17, 1-7. [CrossRef] [PubMed]

54. Mostek, A.; Dietrich, M.A.; Słowińska, M.; Ciereszko, A. Cryopreservation of bull semen is associated with carbonylation of sperm proteins. Theriogenology 2017, 92, 95-102. [CrossRef] [PubMed]

55. Losano, J.; Angrimani, D.; Dalmazzo, A.; Rui, B.; Brito, M.; Mendes, C.; Kawai, G.; Vannucchi, C.; Assumpção, M.; Barnabe, V.; et al. Effect of mitochondrial uncoupling and glycolysis inhibition on ram sperm functionality. Reprod. Domest. Anim. 2017, 52, 289-297. [CrossRef]

56. Naresh, S. Effect of cooling and cryopreservation on cytoskeleton actin and protein tyrosine phosphorylation in buffalo spermatozoa. Cryobiology 2016, 72, 7-13. [CrossRef]

57. Felipe-Pérez, Y.E.; Valencia, J.; Juárez-Mosqueda, M. de L.; Pescador, N.; Roa-Espitia, A.L.; Hernández-González, E.O. Cytoskeletal proteins F-actin and $\beta$-dystrobrevin are altered by the cryopreservation process in bull sperm. Cryobiology 2012, 64, 103-109. [CrossRef]

58. Zhang, X.G.; Hu, S.; Han, C.; Zhu, Q.C.; Yan, G.J.; Hu, J.H. Association of heat shock protein 90 with motility of post-thawed sperm in bulls. Cryobiology 2015, 70, 164-169. [CrossRef]

59. Kumar, M.; Kumar, K.; Jain, S.; Hassan, T.; Dada, R. Novel insights into the genetic and epigenetic paternal contribution to the human embryo. Clinics 2013, 68, 5-14. [CrossRef]

60. Lewis, S.E.M.; Aitken, R.J. DNA damage to spermatozoa has impacts on fertilization and pregnancy. Cell Tissue Res. 2005, 322, 33-41. [CrossRef]

61. Khalifa, T.A.A.; Rekkas, C.A.; Lymberopoulos, A.G.; Sioga, A.; Dimitriadis, I.; Papanikolaou, T. Factors affecting chromatin stability of bovine spermatozoa. Anim. Reprod. Sci. 2008, 104, 143-163. [CrossRef] [PubMed] 
62. Kadirvel, G.; Periasamy, S.; Kumar, S. Effect of cryopreservation on apoptotic-like events and its relationship with cryocapacitation of buffalo (Bubalus bubalis) sperm. Reprod. Domest. Anim. 2012, 47, 143-150. [CrossRef] [PubMed]

63. Martin, G.; Sabido, O.; Durand, P.; Levy, R. Cryopreservation induces an apoptosis-like mechanism in bull sperm. Biol. Reprod. 2004, 71, 28-37. [CrossRef] [PubMed]

64. Van der Schans, G.P.; Haring, R.; van Dijk-Knijnenburg, H.C.M.; Bruijnzeel, P.L.B.; Den Daas, N.H.G. An immunochemical assay to detect DNA damage in bovine sperm. J. Androl. 2000, 21, 250-257.

65. Peris, S.I.; Bilodeau, J.-F.; Dufour, M.; Bailey, J.L. Impact of cryopreservation and reactive oxygen species on DNA integrity, lipid peroxidation, and functional parameters in ram sperm. Mol. Reprod. Dev. 2007, 74, 878-892. [CrossRef] [PubMed]

66. Evenson, D.P. The sperm chromatin structure assay $\left(\mathrm{SCSA}^{\circledR}\right)$ and other sperm DNA fragmentation tests for evaluation of sperm nuclear DNA integrity as related to fertility. Anim. Reprod. Sci. 2016, 169, 56-75. [CrossRef] [PubMed]

67. Gosálvez, J.; López-Fernández, C.; Fernández, J.L.; Gouraud, A.; Holt, W.V. Relationships between the dynamics of iatrogenic DNA damage and genomic design in mammalian spermatozoa from eleven species. Mol. Reprod. Dev. 2011, 78, 951-961.

68. Cortés-Gutiérrez, E.I.; López-Fernández, C.; Fernández, J.L.; Dávila-Rodríguez, M.I.; Johnston, S.D.; Gosálvez, J. Interpreting sperm DNA damage in a diverse range of mammalian sperm by means of the two-tailed comet assay. Front. Genet. 2014, 5, 1-11.

69. Domínguez-Rebolledo, Á.E.; Fernández-Santos, M.R.; García-Álvarez, O.; Maroto-Morales, A.; Garde, J.J.; Martínez-Pastor, F. Washing increases the susceptibility to exogenous oxidative stress in red deer spermatozoa. Theriogenology 2009, 72, 1073-1084. [CrossRef]

70. Martinez-Pastor, F.; Johannisson, A.; Gil, J.; Kaabi, M.; Anel, L.; Paz, P.; Rodriguez-Martinez, H. Use of chromatin stability assay, mitochondrial stain JC-1, and fluorometric assessment of plasma membrane to evaluate frozen-thawed ram semen. Anim. Reprod. Sci. 2004, 84, 121-133. [CrossRef]

71. Peris-Frau, P.; Álvarez-Rodríguez, M.; Martín-Maestro, A.; Iniesta-Cuerda, M.; Sánchez-Ajofrín, I.; Garde, J.J.; Rodriguez-Martinez, H.; Soler, A.J. Comparative evaluation of DNA integrity using sperm chromatin structure assay and Sperm-Ovis-Halomax during in vitro capacitation of cryopreserved ram spermatozoa. Reprod. Domest. Anim. 2019, 54, 46-49. [CrossRef] [PubMed]

72. Yamauchi, Y.; Shaman, J.A.; Ward, W.S. Non-genetic contributions of the sperm nucleus to embryonic development. Asian J. Androl. 2011, 13, 31-35. [CrossRef] [PubMed]

73. Verma, A.; Rajput, S.; De, S.; Kumar, R.; Chakravarty, A.K.; Datta, T.K. Genome-wide pro fi ling of sperm DNA methylation in relation to buffalo (Bubalus bubalis) bull fertility. Theriogenology 2014, 82, 750-759. [CrossRef] [PubMed]

74. Ge, S.; Lin, S.; Zhao, Z.; Sun, Q. Epigenetic dynamics and interplay during spermatogenesis and embryogenesis: Implications for male fertility and offspring health. Oncotarget 2017, 8, 53804-53818. [CrossRef]

75. Collins, L.J.; Schönfeld, B.; Xiaowei, S.C. The epigenetics of non-coding RNA. In Handbook of Epigenetics; Elsevier Inc.: Amsterdam, The Netherlands, 2011; pp. 49-61.

76. Chen, X.; Wang, Y.; Zhu, H.; Hao, H.; Zhao, X.; Qin, T.; Wang, D. Comparative transcript profiling of gene expression of fresh and frozen-thawed bull sperm. Theriogenology 2015, 83, 504-511. [CrossRef]

77. Aurich, C.; Schreiner, B.; Ille, N.; Alvarenga, M.; Scarlet, D. Cytosine methylation of sperm DNA in horse semen after cryopreservation. Theriogenology 2016, 86, 1347-1352. [CrossRef]

78. Zeng, C.; Peng, W.; Ding, L.; He, L.; Zhang, Y.; Fang, D.; Tang, K. A preliminary study on epigenetic changes during boar spermatozoa cryopreservation. Cryobiology 2014, 69, 119-127. [CrossRef]

79. Ortiz-Rodriguez, J.M.; Ortega-Ferrusola, C.; Gil, M.C.; Martín-Cano, F.E.; Gaitskell-Phillips, G.; Rodríguez-Martínez, H.; Hinrichs, K.; Álvarez-Barrientos, A.; Román, Á.; Peña, F.J. Transcriptome analysis reveals that fertilization with cryopreserved sperm downregulates genes relevant for early embryo development in the horse. PLoS ONE 2019, 14, e213420. [CrossRef]

80. Perumal, P.; Savino, N.; Ctr, S.; Mh, K.; Ezung, E.; Chang, S.; Tzt, S. Seasonal effect on physiological, reproductive and fertility profiles in breeding mithun bulls. Asian Pac. J. Reprod. 2017, 6, 268-278. [CrossRef]

81. De Rensis, F.; John, R. Heat stress and seasonal effects on reproduction in the dairy cow-A review. Theriogenology 2003, 60, 1139-1151. [CrossRef] 
82. Al-Dawood, A. Towards heat stress management in small Ruminants-A review. Ann. Anim. Sci. 2017, 17, 59-88. [CrossRef]

83. Santiago-Moreno, J.; Gómez-Brunet, A.; Toledano-Díaz, A.; Picazo, R.; Gonzalez-Bulnes, A.; López-Sebastián, A. Seasonal endocrine changes and breeding activity in mediterranean wild ruminants. Reprod. Domest. Anim. 2006, 41, 72-81. [CrossRef] [PubMed]

84. Martínez-Fresneda, L.; O’Brien, E.; Velázquez, R.; Toledano-Díaz, A.; Martínez-Cáceres, C.M.; Tesfaye, D.; Schellander, K.; García-Vázquez, F.A.; Santiago-Moreno, J. Seasonal variation in sperm freezability associated with changes in testicular germinal epithelium in domestic (Ovis aries) and wild (Ovis musimon) sheep. Reprod. Fertil. Dev. 2019, 31, 1545-1557. [CrossRef] [PubMed]

85. Argov-Argaman, N.; Mahgrefthe, K.; Zeron, Y.; Roth, Z. Season-induced variation in lipid composition is associated with semen quality in Holstein bulls. Reproduction 2013, 145, 479-489. [CrossRef] [PubMed]

86. Westfalewicz, B.; Dietrich, M.; Słowińska, M.; Judycka, S.; Ciereszko, A. Seasonal changes in the proteome of cryopreserved bull semen supernatant. Theriogenology 2019, 126, 295-302. [CrossRef] [PubMed]

87. Muiño-Blanco, T.; Pérez-Pé, R.; Cebrián-Pérez, J.A. Seminal plasma proteins and sperm resistance to stress. Reprod. Domest. Anim. 2008, 43, 18-31. [CrossRef] [PubMed]

88. Domínguez, M.P.; Falcinelli, A.; Hozbor, F.; Sánchez, E.; Cesari, A.; Alberio, R.H. Seasonal variations in the composition of ram seminal plasma and its effect on frozen-thawed ram sperm. Theriogenology 2008, 69, 564-573. [CrossRef]

89. Leahy, T.; Marti, J.I.; Evans, G.; Maxwell, W.M.C. Seasonal variation in the protective effect of seminal plasma on frozen-thawed ram spermatozoa. Anim. Reprod. Sci. 2010, 119, 147-153. [CrossRef]

90. Morató, R.; Prieto-Martínez, N.; Muiño, R.; Hidalgo, C.O.; Rodríguez-Gil, J.E.; Bonet, S.; Yeste, M. Aquaporin 11 is related to cryotolerance and fertilising ability of frozen-thawed bull spermatozoa. Reprod. Fertil. Dev. 2018, 30, 1099-1108. [CrossRef]

91. Ryu, D.Y.; Song, W.H.; Pang, W.K.; Yoon, S.J.; Rahman, M.S.; Pang, M.G. Freezability biomarkers in bull epididymal spermatozoa. Sci. Rep. 2019, 9, 1-9. [CrossRef]

92. Wang, P.; Wang, Y.F.; Wang, H.; Wang, C.W.; Zan, L.S.; Hu, J.H.; Li, Q.W.; Jia, Y.H.; Ma, G.J. HSP90 expression correlation with the freezing resistance of bull sperm. Zygote 2014, 22, 239-245. [CrossRef] [PubMed]

93. Rickard, J.P.; Leahy, T.; Soleilhavoup, C.; Tsikis, G.; Labas, V.; Harichaux, G.; Lynch, G.W.; Druart, X.; de Graaf, S.P. The identification of proteomic markers of sperm freezing resilience in ram seminal plasma. J. Proteom. 2015, 126, 303-311. [CrossRef] [PubMed]

94. Rego, J.P.A.; Martins, J.M.; Wolf, C.A.; Van Tilburg, M.; Moreno, F.; Monteiro-Moreira, A.C.; Moreira, R.A.; Santos, D.O.; Moura, A.A. Proteomic analysis of seminal plasma and sperm cells and their associations with semen freezability in Guzerat bulls. J. Anim. Sci. 2016, 94, 5308-5320. [CrossRef] [PubMed]

95. Song, W.H.; Ryu, D.Y.; Pang, W.K.; Yoon, S.J.; Rahman, M.S.; Pang, M.G. NT5C1B and FH are closely associated with cryoprotectant tolerance in spermatozoa. Andrology 2019, 8, 221-230. [CrossRef] [PubMed]

96. Karunakaran, M.; Gajare, V.C.; Mandal, A.; Mondal, M.; Das, S.K.; Ghosh, M.K.; Rai, S.; Behera, R. Electrophoretic profile of seminal proteins and their correlation with in vitro sperm characters in Black Bengal buck semen. Vet. World 2019, 12, 621-628. [CrossRef] [PubMed]

97. Rickard, J.P.; Schmidt, R.E.; Maddison, J.W.; Bathgate, R.; Lynch, G.W.; Druart, X.; De Graaf, S.P. Variation in seminal plasma alters the ability of ram spermatozoa to survive cryopreservation. Reprod. Fertil. Dev. 2016, 28, 516-523. [CrossRef] [PubMed]

98. Soler, A.; García, A.; Fernández-Santos, M.; Esteso, M.; Garde, J. Effects of thawing procedure on postthawed in vitro viability and in vivo fertility of Red Deer epididymal. J. Androl. 2003, 24, 746-756. [CrossRef]

99. Fujii, T.; Hirayama, H.; Fukuda, S.; Kageyama, S.; Naito, A.; Yoshino, H.; Moriyasu, S.; Yamazaki, T.; Sakamoto, K.; Hayakawa, H.; et al. Expression and localization of aquaporins 3 and 7 in bull spermatozoa and their relevance to sperm motility after cryopreservation. J. Reprod. Dev. 2018, 64, 327-335. [CrossRef]

100. Prieto-Martínez, N.; Morató, R.; Muiño, R.; Hidalgo, C.O.; Rodríguez-Gil, J.E.; Bonet, S.; Yeste, M. Aquaglyceroporins 3 and 7 in bull spermatozoa: Identification, localisation and their relationship with sperm cryotolerance. Reprod. Fertil. Dev. 2017, 29, 1249-1259. [CrossRef]

101. Jobim, M.I.M.; Oberst, E.R.; Salbego, C.; Souza, D.; Wald, V.B.; Tramontina, F.; Mattos, R.C. Two-dimensional polyacrylamide gel electrophoresis of bovine seminal plasma proteins and their relation with semen freezability. Theriogenology 2004, 61, 255-266. [CrossRef] 
102. Pereira, R.M.; Mesquita, P.; Pires, V.M.R.; Baptista, M.C.; Barbas, J.P.; Pimenta, J.; Horta, A.E.M.; Prates, J.A.M.; Marques, C.C. Prion protein testis specific (PRNT) gene polymorphisms and transcript level in ovine spermatozoa: Implications in freezability, fertilization and embryo production. Theriogenology 2018, 115, 124-132. [CrossRef] [PubMed]

103. Kaminski, S.; Hering, D.M.; Kordan, W.; Lecewicz, M. Missense mutation within cystic fibrosis transmembrane conductance regulator (CFTR) gene is associated with selected parameters of the frozen-thawed sperm in Holstein-Friesian bulls. Pol. J. Vet. Sci. 2019, 22, 221-225. [PubMed]

104. Nikbin, S.; Panandam, J.M.; Yaakub, H.; Murugaiyah, M.; Sazili, A.Q. Novel SNPs in heat shock protein 70 gene and their association with sperm quality traits of Boer goats and Boer crosses. Anim. Reprod. Sci. 2014, 146, 176-181. [CrossRef]

105. Petrunkina, A.M.; Waberski, D.; Günzel-Apel, A.R.; Töpfer-Petersen, E. Determinants of sperm quality and fertility in domestic species. Reproduction 2007, 134, 3-17. [CrossRef]

106. Maroto-Morales, A.; Ramón, M.; García-Álvarez, O.; Soler, A.J.; Fernández-Santos, M.R.; Roldan, E.R.S.; Gomendio, M.; Pérez-Guzmán, M.D.; Garde, J.J. Morphometrically-distinct sperm subpopulations defined by a multistep statistical procedure in Ram ejaculates: Intra-And interindividual variation. Theriogenology 2012, 77, 1529-1539. [CrossRef]

107. Esteso, M.C.; Fernández-Santos, M.R.; Soler, A.J.; Montoro, V.; Quintero-Moreno, A.; Garde, J.J. The effects of cryopreservation on the morphometric dimensions of Iberian red deer (Cervus elaphus hispanicus) epididymal sperm heads. Reprod. Domest. Anim. 2006, 41, 241-246. [CrossRef] [PubMed]

108. Muiño, R.; Peña, A.I.; Rodríguez, A.; Tamargo, C.; Hidalgo, C.O. Effects of cryopreservation on the motile sperm subpopulations in semen from Asturiana de los Valles bulls. Theriogenology 2009, 72, 860-868. [CrossRef] [PubMed]

109. Barbas, J.P.; Leahy, T.; Horta, A.E.; García-Herreros, M. Sperm kinematics and subpopulational responses during the cryopreservation process in caprine ejaculates. Cryobiology 2018, 82, 137-147. [CrossRef] [PubMed]

110. Ramón, M.; Pérez-Guzmán, M.D.; Jiménez-Rabadán, P.; Esteso, M.C.; García-Álvarez, O.; Maroto-Morales, A.; Anel-López, L.; Soler, A.J.; Fernández-Santos, M.R.; Garde, J.J. Sperm cell population dynamics in ram semen during the cryopreservation process. PLOS ONE 2013, 8, e59189. [CrossRef]

111. D'Amours, O.; Frenette, G.; Bourassa, S.; Calvo, É.; Blondin, P.; Sullivan, R. Proteomic markers of functional sperm population in bovines: Comparison of low- and high-density spermatozoa following cryopreservation. J. Proteome Res. 2018, 17, 177-188. [CrossRef]

112. Ortega-Ferrusola, C.; Gil, M.C.; Rodríguez-Martínez, H.; Anel, L.; Peña, F.J.; Martín-Muñoz, P. Flow cytometry in spermatology: A bright future ahead. Reprod. Domest. Anim. 2017, 52, 921-931. [CrossRef] [PubMed]

113. Martínez-Fresneda, L.; Castaño, C.; Bóveda, P.; Tesfaye, D.; Schellander, K.; Santiago-Moreno, J.; García-Vázquez, F.A. Epididymal and ejaculated sperm differ on their response to the cryopreservation and capacitation processes in mouflon (Ovis musimon). Sci. Rep. 2019, 9, 1-13. [CrossRef]

114. Quinn, P.J.; White, I.G. Phospholipid and cholesterol content of epididymal and ejaculated ram spermatozoa and seminal plasma in relation to cold shock. Aust. J. Biol. Sci. 1967, 20, 1205-1215. [CrossRef]

115. Pini, T.; Leahy, T.; Soleilhavoup, C.; Tsikis, G.; Labas, V.; Combes-Soia, L.; Harichaux, G.; Rickard, J.P.; Druart, X.; De Graaf, S.P. Proteomic investigation of ram spermatozoa and the proteins conferred by seminal plasma. J. Proteome Res. 2016, 15, 3700-3711. [CrossRef] [PubMed]

116. Perez-Patiño, C.; Barranco, I.; Li, J.; Padilla, L.; Martinez, E.A.; Rodriguez-Martinez, H.; Roca, J.; Parrilla, I. Cryopreservation differentially alters the proteome of epididymal and ejaculated pig spermatozoa. Int. J. Mol. Sci. 2019, 20, 1791. [CrossRef] [PubMed]

117. Bernardini, A.; Hozbor, F.; Sanchez, E.; Fornés, M.W.; Alberio, R.H.; Cesari, A. Conserved ram seminal plasma proteins bind to the sperm membrane and repair cryopreservation damage. Theriogenology 2011, 76, 436-447. [CrossRef]

118. Leahy, T.; Rickard, J.P.; Bernecic, N.C.; Druart, X.; De Graaf, S. Ram seminal plasma and its functional proteomic assessment. Reproduction 2019, 157, 243-256. [CrossRef]

119. Manjunath, P.; Bergeron, A.; Lefebvre, J.; Fan, J. Seminal plasma proteins: Functions and interaction with protective agents during semen preservation. Soc. Reprod. Fertil. Suppl. 2007, 65, 217-228.

120. Pini, T.; Farmer, K.; Druart, X.; Teixeira-gomes, A.P.; Tsikis, G.; Labas, V.; Leahy, T.; Graaf, S.P. De Binder of Sperm Proteins protect ram spermatozoa from freeze-thaw damage. Cryobiology 2018, 82, 78-87. [CrossRef] 
121. Layek, S.S.; Mohanty, T.K.; Kumaresan, A.; Parks, J.E. Cryopreservation of bull semen: Evolution from egg yolk based to soybean based extenders. Anim. Reprod. Sci. 2016, 172, 1-9. [CrossRef]

122. Barbas, J.P.; Mascarenhas, R.D. Cryopreservation of domestic animal sperm cells. Cell Tissue Bank 2009, 10, 49-62. [CrossRef] [PubMed]

123. Allai, L.; Benmoula, A.; Marciane da Silva, M.; Nasser, B.; El Amiri, B. Supplementation of ram semen extender to improve seminal quality and fertility rate. Anim. Reprod. Sci. 2018, 192, 6-17. [CrossRef] [PubMed]

124. Purdy, P.H. A review on goat sperm cryopreservation. Small Rumin. Res. 2006, 63, 215-225. [CrossRef]

125. Mata-Campuzano, M.; Álvarez-Rodríguez, M.; Álvarez, M.; Tamayo-Canul, J.; Anel, L.; De Paz, P.; Martínez-Pastor, F. Post-thawing quality and incubation resilience of cryopreserved ram spermatozoa are affected by antioxidant supplementation and choice of extender. Theriogenology 2015, 83, 520-528. [CrossRef] [PubMed]

126. Fernández-Santos, M.R.; Martínez-Pastor, F.; García-Macías, V.; Esteso, M.C.; Soler, A.J.; de Paz, P.; Anel, L.; Garde, J.J. Extender osmolality and sugar supplementation exert a complex effect on the cryopreservation of Iberian red deer (Cervus elaphus hispanicus) epididymal spermatozoa. Theriogenology 2007, 67, 738-753. [CrossRef]

127. Iqbal, S.; Naz, S.; Ahmed, H.; Andrabi, S.M.H. Cryoprotectant effect of trehalose in extender on post-thaw quality and in vivo fertility of water buffalo (Bubalus bubalis) bull spermatozoa. Andrologia 2018, 50, 1-6. [CrossRef]

128. Hu, J.H.; Zan, L.S.; Zhao, X.L.; Li, Q.W.; Jiang, Z.L.; Li, Y.K.; Li, X. Effects of trehalose supplementation on semen quality and oxidative stress variables in frozen-thawed bovine semen. J. Anim. Sci. 2010, 88, 1657-1662. [CrossRef]

129. Aboagla, E.M.E.; Terada, T. Trehalose-enhanced fluidity of the goat sperm membrane and its protection during freezing. Biol. Reprod. 2003, 69, 1245-1250. [CrossRef]

130. Rostami, B.; Ebrahimi, D.; Sadeghipanah, H.; Masoumi, R.; Shahir, M.H. Effects of supplementation of tris-egg yolk extender with different sugars and antioxidants on freezability of ram semen. Cryobiology 2019. [CrossRef]

131. Fujikawa, T.; Imamura, S.; Tokumaru, M.; Ando, T.; Gen, Y.; Hyon, S.H.; Kubota, C. Cryoprotective effect of antifreeze polyamino-acid (Carboxylated Poly-L-Lysine) on bovine sperm: A technical note. Cryobiology 2018, 82, 159-162. [CrossRef]

132. Tariq, A.; Ahmad, M.; Iqbal, S.; Riaz, M.I.; Tahir, M.Z.; Ghafoor, A.; Riaz, A. Effect of carboxylated poly L-Lysine as a cryoprotectant on post-thaw quality and in vivo fertility of Nili Ravi buffalo (Bubalus bubalis) bull semen. Theriogenology 2020, 144, 8-15. [CrossRef] [PubMed]

133. Longobardi, V.; Albero, G.; De Canditiis, C.; Salzano, A.; Natale, A.; Balestrieri, A.; Neglia, G.; Campanile, G.; Gasparrini, B. Cholesterol-loaded cyclodextrins prevent cryocapacitation damages in buffalo (Bubalus bubalis) cryopreserved sperm. Theriogenology 2017, 89, 359-364. [CrossRef] [PubMed]

134. Mocé, E.; Purdy, P.H.; Graham, J.K. Treating ram sperm with cholesterol-loaded cyclodextrins improves cryosurvival. Anim. Reprod. Sci. 2010, 118, 236-247. [CrossRef] [PubMed]

135. Purdy, P.H.; Graham, J.K. Effect of cholesterol-loaded cyclodextrin on the cryosurvival of bull sperm. Cryobiology 2004, 48, 36-45. [CrossRef] [PubMed]

136. Salmon, V.M.; Leclerc, P.; Bailey, J.L.; Animales, S.; Al, S.E.T. Cholesterol-loaded cyclodextrin increases the cholesterol content of goat sperm to improve cold and osmotic resistance and maintain sperm function after cryopreservation. Biol. Reprod. 2016, 94, 85. [CrossRef]

137. Batissaco, L.; De Arruda, R.P.; Alves, M.B.R.; Torres, M.A.; Lemes, K.M.; Prado-Filho, R.R.; De Almeida, T.G.; De Andrade, A.F.C.; Celeghini, E.C.C. Cholesterol-loaded cyclodextrin is efficient in preserving sperm quality of cryopreserved ram semen with low freezability. Reprod. Biol. 2020, 20, 14-24. [CrossRef]

138. Fernández-Santos, M.R.; Martínez-Pastor, F.; García-Macías, V.; Esteso, M.C.; Soler, A.J.; Paz, P.; Anel, L.; Garde, J.J. Sperm characteristics and DNA integrity of Iberian red deer (Cervus elaphus hispanicus) epididymal spermatozoa frozen in the presence of enzymatic and nonenzymatic antioxidants. J. Androl. 2007, 28, 294-305. [CrossRef]

139. Sánchez-Rubio, F.; Fernández-Santos, M.R.; Castro-Vázquez, L.; García-Álvarez, O.; Maroto-Morales, A.; Soler, A.J.; Martínez-Pastor, F.; Garde, J.J. Cinnamtannin B-1, a novel antioxidant for sperm in red deer. Anim. Reprod. Sci. 2018, 195, 44-52. [CrossRef] 
140. Khalil, W.A.; El-Harairy, M.A.; Zeidan, A.E.B.; Hassan, M.A.E. Impact of selenium nano-particles in semen extender on bull sperm quality after cryopreservation. Theriogenology 2019, 126, 121-127. [CrossRef]

141. Hozyen, H.F.; Shamy, A.A.E.; Farghali, A.A. In vitro Supplementation of nano selenium minimizes freeze-thaw induced damage to ram spermatozoa. Int. J. Vet. Sci. 2019, 8, 249-254.

142. Shahin, M.A.; Khalil, W.A.; Saadeldin, I.M.; Swelum, A.A.-A.; El-harairy, M.A. Comparison between the effects of adding vitamins, trace elements, and nanoparticles to SHOTOR extender on the cryopreservation of dromedary camel epididymal spermatozoa. Animals 2020, 10, 78. [CrossRef] [PubMed]

143. Dashtestani, F.; Ghourchian, H.; Najafi, A. Silver-gold-apoferritin nanozyme for suppressing oxidative stress during cryopreservation. Mater. Sci. Eng. C 2019, 94, 831-840. [CrossRef] [PubMed]

144. Cebrián-Pérez, J.A.; González-Arto, M.; Dos Santos Hamilton, T.R.; Pérez-Pé, R.; Muiño-Blanco, T. Melatonin in sperm biology: Breaking paradigms. Reprod. Domest. Anim. 2014, 49, 11-21. [CrossRef] [PubMed]

145. Ashrafi, I.; Kohram, H.; Ardabili, F.F. Antioxidative effects of melatonin on kinetics, microscopic and oxidative parameters of cryopreserved bull spermatozoa. Anim. Reprod. Sci. 2013, 139, 25-30. [CrossRef] [PubMed]

146. Fang, Y.; Zhao, C.; Xiang, H.; Zhao, X.; Zhong, R. Melatonin inhibits formation of mitochondrial permeability transition pores and improves oxidative phosphorylation of frozen-thawed ram sperm. Front. Endocrinol. 2020, 10, 896. [CrossRef]

147. Ferrusola, C.O.; Fernández, L.G.; Sandoval, C.S.; García, B.M.; Martínez, H.R.; Tapia, J.A.; Peña, F.J. Inhibition of the mitochondrial permeability transition pore reduces "apoptosis like" changes during cryopreservation of stallion spermatozoa. Theriogenology 2010, 74, 458-465. [CrossRef]

148. Pillai, H.; Parmar, M.S.; Shende, A.M.; Thomas, J.; Kartha, H.S.; Sharma, T.; Ghosh, G.S.K.; Kumaresan, A.; Bhure, S.K. Effect of supplementation of recombinant regucalcin in extender on cryopreservation of spermatozoa of water buffalo (Bubalus bubalis). Mol. Reprod. Dev. 2017, 84, 1133-1139. [CrossRef]

149. Ledesma, A.; Zalazar, L.; Buchelly, F.; Ignacio, J.; Brown, P.; Mitch, E.; Hozbor, F.; Cesari, A. Recombinant peptide reverses cryo-capacitation in ram sperm and improves in vitro fertilization. Anim. Reprod. Sci. 2019, 207, 61-72. [CrossRef]

150. Zalazar, L.; Iniesta-Cuerda, M.; Sánchez-Ajofrín, I.; Soler, A.J.; Garde, J.J.; Cesari, A. Recombinant SPINK3 improves ram sperm quality and in vitro fertility after cryopreservation. Theriogenology 2020, 144, 45-55. [CrossRef]

151. Ramírez-Vasquez, R.; Cesari, A.; Hozbor, F.; Greco, M.B.; Cano, A. Extenders modify the seminal plasma ability to minimize freeze-thaw damage on ram sperm. Reprod. Domest. Anim. 2019, 54, 1621-1629. [CrossRef]

152. Robles, V.; Valcarce, D.G.; Riesco, M.F. The use of antifreeze proteins in the cryopreservation of gametes and embryos. Biomolecules 2019, 9, 181. [CrossRef] [PubMed]

153. Payne, S.R.; Oliver, J.E.; Upreti, G.C. Effect of antifreeze proteins on the motility of ram spermatozoa. Cryobiology 1994, 31, 180-184. [CrossRef] [PubMed]

154. Prathalingam, N.S.; Holt, W.V.; Revell, S.G.; Mirczuk, S.; Fleck, R.A.; Watson, P.F. Impact of antifreeze proteins and antifreeze glycoproteins on bovine sperm during freeze-thaw. Theriogenology 2006, 66, 1894-1900. [CrossRef]

155. Qadeer, S.; Khan, M.A.; Ansari, M.S.; Rakha, B.A.; Ejaz, R.; Husna, A.U.; Ashiq, M.; Iqbal, R.; Ullah, N.; Akhter, S. Evaluation of antifreeze protein III for cryopreservation of Nili-Ravi (Bubalus bubalis) buffalo bull sperm. Anim. Reprod. Sci. 2014, 148, 26-31. [CrossRef] [PubMed]

156. Qadeer, S.; Khan, M.A.; Ansari, M.S.; Rakha, B.A.; Ejaz, R.; Iqbal, R.; Younis, M.; Ullah, N.; DeVries, A.L.; Akhter, S. Efficiency of antifreeze glycoproteins for cryopreservation of Nili-Ravi (Bubalus bubalis) buffalo bull sperm. Anim. Reprod. Sci. 2015, 157, 56-62. [CrossRef] [PubMed]

157. Qadeer, S.; Khan, M.A.; Shahzad, Q.; Azam, A.; Ansari, M.S.; Rakha, B.A.; Ejaz, R.; Husna, A.U.; Duman, J.G.; Akhter, S. Efficiency of beetle (Dendroides canadensis) recombinant antifreeze protein for buffalo semen freezability and fertility. Theriogenology 2016, 86, 1662-1669. [CrossRef] [PubMed]

158. Arando, A.; Gonzalez, A.; Delgado, J.V.; Arrebola, F.A.; Perez-Marín, C.C. Storage temperature and sucrose concentrations affect ram sperm quality after vitrification. Anim. Reprod. Sci. 2017, 181, 175-185. [CrossRef]

159. Jiménez-Rabadán, P.; García-Álvarez, O.; Vidal, A.; Maroto-Morales, A.; Iniesta-Cuerda, M.; Ramón, M.; del Olmo, E.; Fernández-Santos, R.; Garde, J.J.; Soler, A.J. Effects of vitrification on ram spermatozoa using free-egg yolk extenders. Cryobiology 2015, 71, 85-90. [CrossRef] 
160. Pradiee, J.; Esteso, M.C.; Castaño, C.; Toledano-Díaz, A.; Lopez-Sebastián, A.; Guerra, R.; Santiago-Moreno, J. Conventional slow freezing cryopreserves mouflon spermatozoa better than vitrification. Andrologia 2017, 49, 1-7. [CrossRef]

161. Pradieé, J.; Sánchez-Calabuig, M.J.; Castaño, C.; O’Brien, E.; Esteso, M.C.; Beltrán-Breña, P.; Maillo, V.; Santiago-Moreno, J.; Rizos, D. Fertilizing capacity of vitrified epididymal sperm from Iberian ibex (Capra pyrenaica). Theriogenology 2018, 108, 314-320. [CrossRef]

(c) (

(C) 2020 by the authors. Licensee MDPI, Basel, Switzerland. This article is an open access article distributed under the terms and conditions of the Creative Commons Attribution (CC BY) license (http://creativecommons.org/licenses/by/4.0/). 